\title{
Mudassir Husnain,
}

International Islamic University Islamabad, Pakistan

ORCID ID, 0000-0002-0735-320X

email: Mudassir.phdmkt14@iiu.edu.pk

Fauzia Syed,

Ph.D., International Islamic University Islamabad, Pakistan

ORCID ID, 0000-0002-1921-0986

email: Fauzia.syed@iiu.edu.pk

Waheed Akhtar,

International Islamic University Islamabad, Pakistan

ORCID ID, 0000-0001-5564-0724

email: waheedakhtarms@gmail.com

Muhammad Usman,

Ph.D., University of Education, Pakistan

ORCID ID, 0000-0002-2594-242X

email:m.usman@ue.edu.pk

Correspondence author: Mudassir.phdmkt14@iiu.edu.pk

\section{EFFECTS OF BRAND HATE ON BRAND EQUITY: THE ROLE OF CORPORATE SOCIAL IRRESPONSIBILITY AND SIMILAR COMPETITOR OFFER}

Abstract. This paper summarises the arguments and counterarguments based on the assumptions of the theory of hate. The study is aimed at testing the mediating role of brand hate elicited in the relationship among the similar competitor offer, corporate social irresponsibility and brand equity. The study sample consisted of 550 participants from the education sector in Pakistan. The methodological tool of the research was structural equation modelling. Purposive sampling technique was used to reach the appropriate respondents for the study. This study was timelagged conducted in three times data periods: in Time $1 \mathrm{a}$ total of 800 surveys were distributed, out of which 722 were returned from respondents; in Time 2722 surveys were distributed to same respondents, out of which 600 were returned; in Time 3600 sunveys were again distributed to the same respondents, out of which 550 were returned. The obtained results confirmed the mediating role of brand hate. Herewith, findings revealed that due to similar offers individual feelings such as loss of self-individuality usually developed and be negatively perceived. Thus, it yields to decline in product value. Likewise, corporate social irresponsibility found to have a more negative relationship with brand equity. Results of the current study revealed that negative feelings due to the similarity in competitor offer could stem from diverse sources. Therefore, it could result in an undesired personality self-loss, if a brand represented a similar brand as its competitors ultimately perceived negative and yielded a decline in value of product/service. The current study also unveiled that corporate social irresponsibility is a strong predictor of negative feelings. Corporate social irresponsibility motivates consumers towards brand hate, thus hampering brand equity. According to the mentioned above, there must be careful management of corporate social responsibility to avoid the negative effect on brand equity. In turn, brand hate mediating the relationship between similarity to competitor offer and brand equity alters consumer perception towards a brand. Thus, companies must fulfil consumers' expectations to minimise brand hate which eventually increases brand equity. This study stands novel and considered as the first attempt to empirically explore the role of similarity to competitor offer and corporate social irresponsibility in eliciting brand hate that could adversely affect on brand equity. The study provided the limitations for future researchers, implications for managers and future directions.

Keywords: duplex theory of hate, tetra-Pak consumer, similar competitor offer, brand hate, brand equity, corporate social irresponsibility.

Cite as: Husnain, M., Syed, F, Akhtar, W., Usman, M. (2020). Effects of Brand Hate on Brand Equity: The Role of Corporate Social Irresponsibility and Similar Competitor Offer. Marketing and Management of Innovations, 3, 75-86. http://doi.org/10.21272/mmi.2020.3-06 
M., Husnain, F., Syed, W., Akhtar, M. Usman. Effects of Brand Hate on Brand Equity: The Role of Corporate Social Irresponsibility and Similar Competitor Offer

Introduction. Health and food safety issues have recently started gaining increased attention from practitioners as well as consumers (Farooq et al., 2016). All dairy products, especially milk, have high nutritional value and worldwide consumed daily (Schmidt et al., 2017). Despite the centrality of the benefits mentioned above, previous studies also showed that dairy products consumption had a positive influence on different diseases like obesity (Barrea et al., 2017), hypertension (Gopinath et al., 2014) diabetes (Moslehi and Deininger, 2015).

According to the research (Ojha et al., 2017), in developing countries, including Pakistan, India, and Bangladesh, adulteration of milk was the most dangerous practice. Heating of milk is done using various technological steps which result in chemical modifications in milk proteins To preserve extending shelf-life and microbiological safety (Arena et al., 2017). Following the above backdrops, tetra-Pak milk consumption has declined exponentially in Pakistan for the last few years after reporting poor quality and adulteration (Zaheer, 2017). Therefore, the consumers become consciously suspicious about tetra-Pak milk quality. According to the Pakistan Council of Scientific and Industrial Research, just six milk brands out of 36 tetra-Pak milk, found fit for consumption in Pakistan (Reporter, 2017). Such feelings of consumers in dissatisfaction are more difficult to describe and usually results in consumers' patronage cessation/reduction, complaining/boycotting of a product or service (Zarantonello et al., 2016).

Due to such negative consumption experiences, there is the consumer state of dissatisfaction usually arising negative emotions such as disgust, anger, fear and contempt (Khan and Lee, 2014; Zhang, 2017). In turn, feeling of hate which is a negative emotion towards a brand (Bryson et al., 2013) leads to a negative effect on its brand equity (Rodrigues and Karlsson, 2015). This consumer negativity towards brands in consumer marketing has not much-gained importance and often fallen in the back burner. Kucuk (2008) found that feeling of hate directly or indirectly affects consumer perception of the targeted brand image, identity and consumer purchase decision. The current study intends to shed lights on some additional aspects why consumers feel cynical about brands and consequently, the adverse effect of these feelings toward brand equity.

Through a theoretical perspective, this research offers the basis for researchers interested in this area for further study. At the first time, the current study will make addition in literature by examining the role of similar offers of the competitor and corporate social irresponsibility (CSI) activating the feeling of hate and subsequently on brand equity. This research is an extension of the previous qualitative studies by conducting the quantitative approach to brand hate and its negative impact on brand equity (Hegner et al., 2017). From a managerial perspective, brand hate studies depict that brand haters have a foremost adverse impact on firms (Zarantonello et al., 2016).

Literature Review. According to the study (Sternberg, 2003), hate is an emotion. However, there are reasons to assume that there are multiple components of hate which may be observed on different occasions in different ways. The duplex theory of hate provides three hate components as follows: the negation of intimacy, passion and decision/commitment. Moreover, the negation of intimacy means seeking distance because of repulsion and disgust. Due to this component, consumer intentionally makes the distance from the brand, that is the reason for negative feelings. In turn, passion means fear to avoid due to anger. The negative feelings that arise from this component are due to anger. Thus, the consumer avoids such brand. The decision/commitment component means the devaluation and diminution through contempt. Herewith, the consumer has the impression in the brand's contempt against his self-image due to which evaluation and diminution had occurred. Generated by these components feelings resulted from the violation of moral codes. In turn, it leads to an increase in hate and subsequently decreases in brand equity of the brand.

Brand equity is a differential effect, recognising the brand name has on consumers' reaction towards a product or its marketing (Kotler and Armstrong, 2010). During the last few decades, owing to the significant role of brand equity as the valuable intangible firm asset it has become one of the main attentive 
M., Husnain, F., Syed, W., Akhtar, M. Usman. Effects of Brand Hate on Brand Equity: The Role of Corporate Social Irresponsibility and Similar Competitor Offer

areas for marketing practitioners and managers (Farjam and Hongyi, 2015). The brand is considered as the most valuable asset for firms. Therefore marketers adopt various strategies to build strong consumerbased brand equity (Emari et al., 2012). Amongst academic researchers, increasing interest in brand equity has evidenced in immense knowledge regarding brand equity (Yousaf et al., 2017). Brand equity depicts consumers' self-image and the ways they think or feel about themselves as well as the ways they suppose others perceive them when utilising brands (Shuv-Ami, 2012). A more reliable brand with positive brand equity has many benefits like high margins, powerful communication effectiveness, brand extension opportunities, high preference of consumers and their purchase intention (Buil et al., 2013; Su, 2016) ultimately.

According to Brewer (1991), consumers have an innate desire for balancing their desire for individuality with the willingness of exclusiveness. In particular condition, similarity to competitor offer also generates a state of unwanted, thus creating a negative brand relationship. In the study (Sternberg, 2003), it was found that negative emotions lead towards hate which in turn has adverse effects on brand equity (Abid and Khattak, 2017). Following the mentioned above, if the brand does not meet the consumer requirements, it would negatively impact on brand equity. In the frame of research (Zarantonello et al., 2016), it was confirmed that the brand perceived misfit in respect of personality is the most common antecedent leading towards hate. It should be noted that any violation committed by the brand against the will of the customer leads to negative emotions leading to intentional avoiding the brand. It is worth mentioning that these violations may also include similarity to competitor offers. Product similarity to competitor offer can enhance the brand's prestige greater if similarity with the competitor's product is low (Salem et al., 2014).

The researchers (Hegner et al., 2017), defined brand hate derived from Sternberg's Triangular Theory of Hate as being intense emotional response due to contempt, disgust or anger for the brand. The previous studies investigated the role of similarity to competitor offer plays in combination with other factors such as confusion and lack of knowledge (Wry and Castor, 2017). Therefore, the similarity is the primary factor that adds up in the negative relationship due to which customer intentionally avoids a brand due to not fulfilling the requirements and expectations of the consumers. Gierl and Huettl (2011) also postulated the different conditions in which similarity is not favourable for the brand. While a consumer is offered to a similar brand of competitors than negative feelings will be generated further leading towards brand hate a severe form of negative emotions.

It is also apparent that nowadays if customers perceive themselves the object of being cheated and betrayed (Sternberg, 2003), they give less patronage to brands which perform similar to the competitor, trigger the feelings of anger and ashamed (Romani et al., 2015; Sarkar and Sarkar, 2017). The negative emotions arise when any of the functions is interfering, or threatening self-image of the consumer, i.e. brand offers similarity to its competitor. A brand that is perceived misfit to the personality of customers also generates negative emotions like brand hate (Zarantonello et al., 2016). Thus, the brand that is similar to its competitor may also be a reason for hate. According to Duplex Theory of Hate (Sternberg, 2003), it leads towards dislike, thus generating hate. Corporate social irresponsibility affects more contextual and often focuses on moral or societal actions which leads to the individual desire for self-image (Nenycz-Thiel and Romaniuk, 2011). Studies suggest that consumers not approve such brands which damage the environment or disrespect human rights, just like consumer boycott such brands that are engaged in unethical business practices (Steinman and Wolfrom, 2012). In the scenario, when a brand is surmised of corporate social irresponsibility, the consumer perceives incompatibility with that brand due to moral, social or legal concerns (Romani et al., 2015). Any act against customer desire or self-image, whether it is moral, legal or social generate negative emotions. Moreover, according to Sternberg (2003), any negative emotion leads towards brand hate which further lowers brand equity of that brand (Abid and Khattak, 
M., Husnain, F., Syed, W., Akhtar, M. Usman. Effects of Brand Hate on Brand Equity: The Role of Corporate Social Irresponsibility and Similar Competitor Offer

2017). Thus, if the brand does not meet the moral, legal or social requirements of the customer, it would negatively affect brand equity.

According to Preijers (2016) besides obviously avoiding any harmful act, companies must prevent any consumer perception of irresponsible behaviour to fence off any negative moral emotions, which include brand hate or lead to it. Corporate social irresponsibility instigates adverse reactions of consumer, which may be extremely harmful to a company and very difficult to recover (Grappi et al., 2013). The literature identifies that related contextual elements link to corporate social irresponsibility consumer perceive based on social, moral or legal corporate wrongdoings which lead to negative expressions towards a brand (Sampedro, 2017; Tsarenko and Tojib, 2015). These could arise from deceptive communication, moral misconducts or social incompatibilities of values by the brand (Vance and Harris, 2011). Morally customer prioritises social needs more than individual and resists to those forces that influence negatively on society and believes to avoid such brands is the right thing (Abid and Khattak, 2017). Sternberg (2003) has developed several prototypical stories around the topic of moral violations such as the criminal story in which hatred object has stolen some valuable thing or a seducer story which hurt someone. According (Sternberg, 2003), these violations in codes may sometime due to being betrayed, physically abused or being ashamed. Applying in today's business practices toxic work environment, unethical business practices are the few reasons which even make the corporate public relation department scrambling. The main motive for brand hate concerning moral and social concerns is the corporate social irresponsibility between a firm and customer. Brand hate due to ideological incompatibility is the main reason behind moral avoidance (Lee et al., 2009). These essential elements are resisting forces which societal emphasis fall outside the individuals makes the consumer believe in avoiding some brands. There is scant research on corporate social irresponsibility and its consequences, while several studies have investigated hate as a consequence of immoral behaviour. Bryson et al. (2013) in their qualitative study found no facts regarding moral violations may lead to hate; while several studies have revealed that moral violations can instigate to the feeling of hate (Delzen, 2014). Therefore, it may be revealed that moral, social or societal wrongdoings compel the customer to leave the brand intentionally. Marketers and managers adopt various strategies to build powerful consumer-based brand equity as brands are considered as the most valuable assets for a company (Emari et al., 2012). Brand equity also depicts the consumers' identities and thinking or feeling about themselves, as well as others' thinking perceiving them in case of the brand utilising. A more reliable brand having positive brand equity ultimately contribute to high margins, powerful communication effectiveness, brand extension opportunities, high preference of consumers and their purchase intention (Su, 2016). After giving a basic approach of brand equity by Aaker and Joachimsthaler (2000), several studies have revealed a significant effect of four factors on the brand equity of a brand (Farjam and Hongyi, 2015). Researchers posit that negative brand equity like positive one could also take place in case when brands decrease the perceived value of the product (Keller, 2014; Shamsudin et al., 2019). In some instances, brand avoidance elements lead the consumers being attracted by competing brand to outstrip themselves further from the unliked brands (Rodrigues and Karlsson, 2015). It worth noting that from the firms' view, this could harm brand equity (Lee et al., 2009). Meanwhile relating to behavioural consequences, brand hate directs towards disputatious actions like brand avoidance or consumers hateful behaviour ranging from soft (negative WOM or talking badly) to severe revengeful behaviour (Grégoire et al., 2009). Hate for brands has been discussed as deliberately avoidance or refusing of the brand, and display of behaviours like expressing negative feelings, rejecting, or even damage to company property. Some suggest it is consumers' reaction to punish a brand for the damage that has been done to them or their desire for the distraction from the particular brand (Sampedro, 2017). Dissatisfied consumers either raise their voice through complaining against the company or exiting the relationships with the specific brand. 
M., Husnain, F., Syed, W., Akhtar, M. Usman. Effects of Brand Hate on Brand Equity: The Role of Corporate Social Irresponsibility and Similar Competitor Offer

According to the triangular hate theory, particular determinants act as the causes of hate. In turn, this hate triggers consumers to adopt hate objects and to get revenge or retaliate for the brand's wrongdoings. Specific causes in moral codes trigger feelings of hate among individuals and in turn, propagate adverse outcomes. Thus, the brand hate mediates as the relationships which could be explained through the violation of moral codes once experienced by consumers, create hateful feelings. Therefore, it compels consumers to adopt anti-brand behaviours that ultimately damage its brand equity.

In the case of similar brands, the mediating role of brand hate persists. It worth mentioning that consumers of current era neglecting those brands which are offering similar brands and triggers the feelings of disappointment and anger (Romani et al., 2015; Sarkar and Sarkar, 2017), as they perceive themselves being cheated and betrayed by that brand (Sternberg, 2003). In turn, it creates a plea of intentionally brand avoidance, thus lowering its brand equity (Zhang, 2017). This customers behaviour indicates negative relationships between customer and brand due to which brand decreases the perceived value and customer distract from it. In the case of corporate social irresponsibility, the mediating role of brand hate also exists because consumers of current age ignoring those brands which are involved in moral or unethical wrongdoings against the will of consumers. Subsequently, the mentioned above triggers negative consumers feelings. According to Sternberg (2003), negative feelings leads towards brand hate and consequently lowers its brand equity (Abid and Khattak, 2017). Therefore, the brand that does not meet the legal, moral or social requirements and expectations of customer it will adversely affect brand equity. Previous research has also revealed that consumers didn't accept that brand engaged in unethical business practices and damage the self-image of consumers (Steinman and Wolfrom, 2012).

The systematisation of the scientific background has confirmed that brand hate mediates the relationship between the brand transgressions and anti-brand activism (Romani et al., 2015), brand avoidance and the brand equity (Abid and Khattak, 2017), perceived betrayal and anti-brand action (Romani et al., 2015).

Methodology and research methods. The sample of the study is the individual consumers of tetraPak milk. Notably, in compliance with the earlier studies, male and female tend to respond in different ways regarding dieting behaviours and food choices (Wardle et al., 2004). Data gathered from users (male and female teachers) teaching in different schools. Furthermore, data were collected over three-time spans, thus making it a time-lagged study. However, for causality, temporal precedence is key (Cook and Campbell, 1979). In social science, time lags are ascertained mainly by tradition or convenience (Cole and Maxwell, 2003). Independent variables were tapped in time 1, mediating variable (brand hate) was tapped in time 2, dependent variable (brand equity) was tapped in time 3.

Purposive sampling technique was used to reach the appropriate respondents of the study. Analysis of the scholars' scientific background in the investigating field allowed noticing the different sample sizes ranging from 200 for the simple framework (Kelloway, 1998; Kotrlik and Higgins, 2001) and around 300400 to some extent for complex (Abbas et al., 2014; Jahanzeb and Fatima, 2018). The present study was time-lagged in nature comprising of three times data. For Time 1, a total of 800 surveys were distributed, out of which 722 were returned from respondents. For Time 2, 722 surveys were distributed to the same respondents, out of which 600 were returned. For Time 3600 surveys were again distributed to the same respondents, out of which 550 were returned that seems sufficient for temporal design (Boomsma, 1983). Based on systematic literature from scientific journals review, several hypotheses were proposed as given:

$\mathrm{H} 1$ : Similarity to the competitor has the significant negative effect on brand equity.

$\mathrm{H} 2$ : Similarity to the competitor has the significant positive effect on brand hate.

$\mathrm{H} 3$ : Corporate social irresponsibility has the significant negative effect on brand equity.

$\mathrm{H} 4$ : Corporate social irresponsibility has the significant positive effect on brand hate.

$\mathrm{H} 5$ : Brand hate has the significant negative effect on brand equity. 
M., Husnain, F., Syed, W., Akhtar, M. Usman. Effects of Brand Hate on Brand Equity: The Role of Corporate Social Irresponsibility and Similar Competitor Offer

H6: Brand hate has mediating role in the relationship between a) similarity to competitor offer; b) Corporate social irresponsibility and brand equity.

Results. In demographics, the majority of the respondents were less than 40 years age group (68\%), among them 359 male (65\%) and 191 females (35\%); 394 (72\%) - from the government sector, and $155-(28 \%)$ from the private sector; $8 \%$ were graduates, $79 \%$ - masters, $13 \%$ - M.Phil. and above degree; $50 \%$ of respondents had less than 50000 monthly incomes. By using statistical software AMOS to test the measurement model, Confirmatory Factor Analysis was carried out. Different indices were considered in confirming the fitness of the data including Relative Chi-square (CMIN/DF), Goodness of Fit (GFI), Comparative Fit Index (CFI) and Root Mean Square Residual (RMR). The value of the CMIN/DF is 2.309, an indication which is below 3 , as recommended by Kline (1998). The values of the GFI, AGFI and $\mathrm{CFI}$ are noted to be sample sensitive. The acceptable upper-lower ranges for GFI $(0.88-0.94), \mathrm{AGFI}(0.86$ $0.90)$ and CFI (0.92-0.98) were considered for the sample of 100-200. Therefore, the present study examined 0.9 (Sivo et al., 2006). Accordingly in this study fit indices results shown that CFI, GFI, CMIN/DF, RMSEA, RMR are above threshold 0.929, 0.912, 2.309, 0.055 and 0.048 respectively, showing data fit the model well. Composite reliability (CR) of all the constructs found to have values greater than 0.7 (Table 1) (Bagozzi and Yi, 1988). Additionally, all construct values for average variance extracted (AVE) found above than 0.50 , and factor loadings appear significant at $p<0.001$ level. Table 2 shows discriminant validity was examined and established as constructs having the higher square root of AVE concerning correlations with other variables (Fornell and Larcker, 1981).

Table 1. Convergent Validity

\begin{tabular}{|c|c|c|c|c|c|}
\hline Constructs & Items & $\begin{array}{l}\text { Factor } \\
\text { Loading }\end{array}$ & $\begin{array}{l}\text { Composite } \\
\text { Reliability }\end{array}$ & $\begin{array}{l}\text { Average } \\
\text { Variance } \\
\text { Extracted }\end{array}$ & Cronbach a \\
\hline \multirow{3}{*}{ Similarity to competitor offer } & SCO1 & 0.72 & \multirow{3}{*}{0.801} & \multirow{3}{*}{0.627} & \multirow{3}{*}{0.832} \\
\hline & $\mathrm{SCO} 2$ & 0.93 & & & \\
\hline & $\mathrm{SCO} 3$ & 0.86 & & & \\
\hline \multirow{4}{*}{ Corporate social irresponsibility } & CS1 & 0.73 & \multirow{4}{*}{0.729} & \multirow{4}{*}{0.608} & \multirow{4}{*}{0.788} \\
\hline & CS2 & 0.77 & & & \\
\hline & $\operatorname{cs3}$ & 0.86 & & & \\
\hline & CS4 & 0.68 & & & \\
\hline \multirow{4}{*}{ Brand Hate } & $\mathrm{BH} 1$ & 0.78 & \multirow{4}{*}{0.824} & \multirow{4}{*}{0.683} & \multirow{4}{*}{0.841} \\
\hline & $\mathrm{BH} 2$ & 0.85 & & & \\
\hline & $\mathrm{BH} 3$ & 0.86 & & & \\
\hline & $\mathrm{BH} 4$ & 0.73 & & & \\
\hline \multirow{11}{*}{ Brand Equity } & BA2 & 0.85 & \multirow{11}{*}{0.729} & \multirow{11}{*}{0.618} & \multirow{11}{*}{0.752} \\
\hline & BA3 & 0.86 & & & \\
\hline & BA4 & 0.86 & & & \\
\hline & BL1 & 0.81 & & & \\
\hline & BL2 & 0.77 & & & \\
\hline & $\mathrm{BL3}$ & 0.76 & & & \\
\hline & BAS1 & 0.78 & & & \\
\hline & BAS2 & 0.70 & & & \\
\hline & BAS3 & 0.61 & & & \\
\hline & PQ1 & 0.98 & & & \\
\hline & $P Q 2$ & 0.99 & & & \\
\hline
\end{tabular}

Sources: developed by the authors based on own calculations (2020). 
M., Husnain, F., Syed, W., Akhtar, M. Usman. Effects of Brand Hate on Brand Equity: The Role of Corporate Social Irresponsibility and Similar Competitor Offer

Table 2. Discriminant Validity

\begin{tabular}{ccccc}
\hline & $\begin{array}{c}\text { Similarity to } \\
\text { competitor offer }\end{array}$ & $\begin{array}{c}\text { Corporate social } \\
\text { irresponsibility }\end{array}$ & Brand Hate & Brand Equity \\
\hline $\begin{array}{c}\text { Similarity to } \\
\text { competitor offer }\end{array}$ & $\mathbf{0 . 5 1 8}$ & & & \\
\hline $\begin{array}{c}\text { Corporate social } \\
\text { irresponsibility }\end{array}$ & 0.075 & $\mathbf{0 . 6 2 9}$ & & \\
\hline Brand Hate & 0.071 & 0.130 & $\mathbf{0 . 7 5 1}$ & \\
\hline Brand Equity & -0.097 & -0.509 & -0.133 & $\mathbf{0 . 4 8 2}$ \\
\hline
\end{tabular}

The values in brackets are the square root of (AVE).

Sources: developed by the authors based on their calculations (2020).

Drawing from Table 3 results of the path model shows hypothesis testing and data fit the model well, fit indices $\mathrm{GFI}=0.905, \mathrm{AGFI}=0.897, \mathrm{CFI}=0.922, \mathrm{CMIN} / \mathrm{DF}=2.593$. Table 3 displays the results of hypotheses testing. Based on t-value $>1.96$, analysis reveals and confirms significant path results. Findings show that similarity to competitor offer has the significant negative effect on brand equity $(\beta=$ $12, t=-2.40, p<0.05)$, and positive effect on brand hate $(\beta=0.45, t=9.78, p<0.001)$. Thus, $\mathrm{H} 1$ and $\mathrm{H} 2$ are supported. Also, corporate social irresponsibility has the significant negative relationship with brand equity $(\beta=-20, t=-3.89, p<0.001)$, and positive effect with brand hate $(\beta=67, t=7.39, p=0.002)$. Herewith, brand hate has the significant negative relationship with brand equity $(\beta=-11, t=-2.28$, $\mathrm{p}<0.05)$. Hence, $\mathrm{H} 3, \mathrm{H} 4$ and $\mathrm{H} 5$ are supported.

Table 3. Structural Model Analysis

\begin{tabular}{|c|c|c|c|c|c|c|}
\hline \multicolumn{2}{|c|}{ Relationship } & \multicolumn{3}{|c|}{ Estimate } & \multirow{2}{*}{$\begin{array}{l}\text { C.R. } \\
-2.40\end{array}$} & \multirow{2}{*}{$\begin{array}{l}\mathrm{P} \\
.027\end{array}$} \\
\hline B_Equity & $<<-$ & SCO & -12 & & & \\
\hline B_H & $<-$ & SCO & .45 & & 9.78 & $* * *$ \\
\hline B_Equity & $<--$ & CS & -20 & & -3.89 & *** \\
\hline B_H & $<-$ & CS & 67 & & 7.39 & .002 \\
\hline B_Equity & $<--$ & $\mathrm{BH}$ & -11 & & -2.28 & .041 \\
\hline \multicolumn{2}{|c|}{ Testing Mediation } & \multicolumn{2}{|c|}{ Direct without mediator } & Direct with & diator & Indirect Effect \\
\hline \multicolumn{2}{|c|}{ B_Equity <---BH<--SCO } & \multicolumn{2}{|c|}{$-.12(.027)$} & $-.119(.002)$ & & $.021(.017)$ \\
\hline \multicolumn{2}{|c|}{ B_Equity <---BH<---CS } & \multicolumn{2}{|c|}{$-.20(.000)$} & $-.089(.061)$ & & $.014(.000)$ \\
\hline
\end{tabular}

Critical t-values: *1.96 (significance level $=5 \%$ ), and ${ }^{* *} 2.58$ (significance level $=1 \%$ ), $\mathrm{N}=550$

Sources: developed by the authors based on own calculations (2020).

This study also tested the mediation effect of brand hate in the relationship between similar competitor offer, corporate social irresponsibility and brand equity. To check this, the indirect effects of brand hate in these relationships were examined. The obtained results indicated that 1) SCO and CSI significantly related to brand equity; 2) SCO and CSI significantly associated with brand hate; 3) brand hate associated considerably to brand equity; 4) when the mediator is added path between SCO and CSI should be substantially reduced. First, second and third conditions are substantiated. Additionally, mediation results revealed (Table 3 ) that inclusion of brand hate reduce the variance in brand equity due to similarity to competitor offer from -0.12 to -0.11 and by corporate social irresponsibility from -0.20 to -0.089 thereby, indicating brand hate partially mediates (Figure 1). Thus, $\mathrm{H} 6$ was supported. 


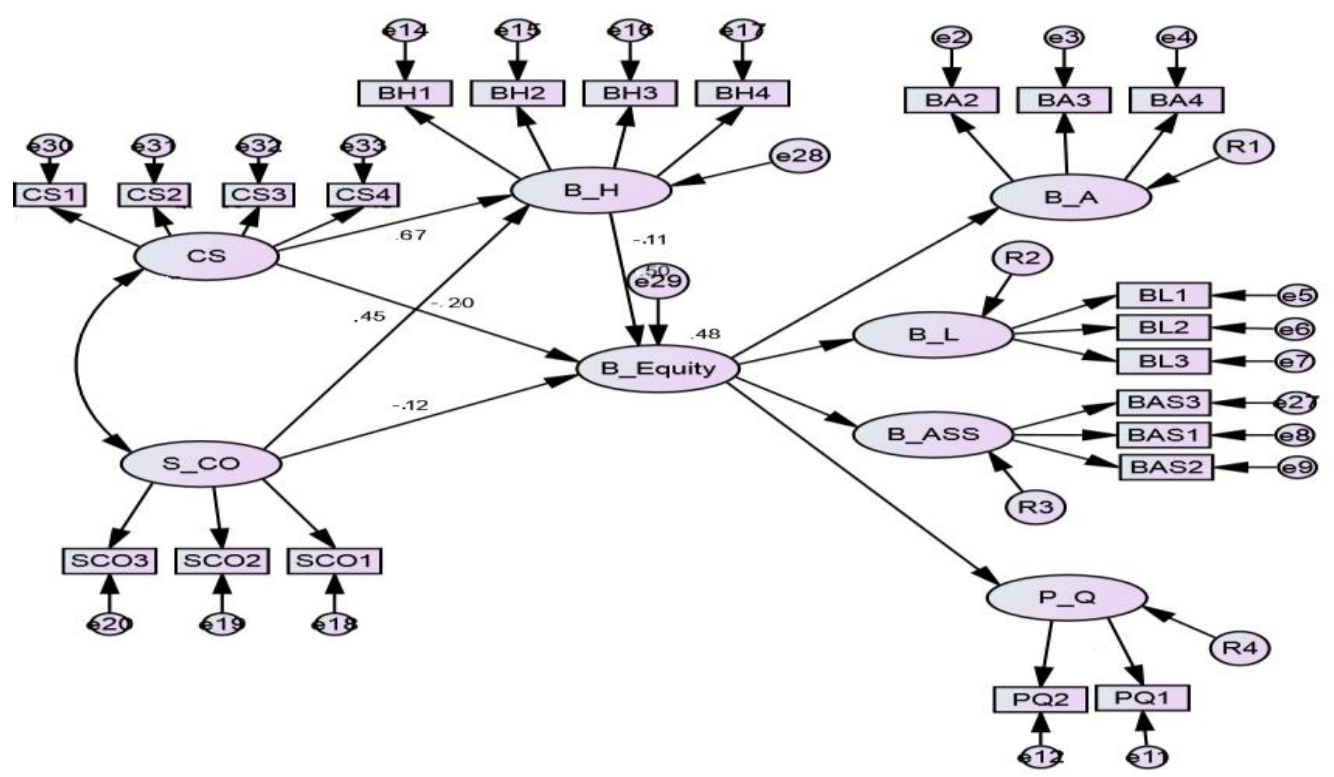

Figure 1. Structural Model

Sources: developed by the authors (2020).

Conclusions. The current study aimed to reveal the effect of similar competitor offer and corporate social irresponsibility on brand equity through brand hate. The obtained results proved that firms should not engage in immoral, social or illegal misconduct, i.e. similar competitor offer and corporate social irresponsibility because these may cause the generation of negative feelings like anger, disgust or disappointment among the customers. The systematisation of scientific background (Klein and Dawar, 2004) indicated that brand equity could protect against consumer switching behaviour due to the positive brand image. Consequently, the negative brand image would be a liability for a firm brand. The negative consumer brand relationship may damage to the company that owns the brand (Fournier and Alvarez, 2013). In turn, this study supports this notion in elaborating that similar competitor offer and corporate social irresponsibility usually result in generating feelings of hate in customers, and they are more likely to reduce brand equity over time. Furthermore, the current study identifies how dynamics of brand hate effect on brand equity in the presence of hateful feelings. There is intense competition amongst tetra-Pak milk companies, having large consumers' volume. These customers generally look for benefits in buying in term of quality. Due to the availability of many tetra-Pak milk brands, there is an excellent opportunity for consumers to switch a brand if not receiving the desired benefits. It also enables companies to get sustainable competitive advantages by having loyal customer and contribute to higher brand equity instead of unfavourable image one which hurts brand equity. It may be assumed that customers start to hate to tetra-Pak milk if the brand is not fulfilling their expectations, whether in quality, customer self-image and moral or ethical codes. Dynamics of brand hate like similarity to competitor offer and corporate social irresponsibility are the primary factors that also add up in negative relationship due to which customer intentionally avoids to that brand. Furthermore, any brand of tetra-Pak milk not meeting the expectations and not performing the function according to customers' requirements (e.g. similarity to competitor offer or corporate social irresponsibility) leading them to brand hate which further links to negative brand equity. This article presented the mediating role of brand hate in the relationship between corporate social irresponsibility and brand equity. Thus, violations of moral, social or ethical codes generate intense 
M., Husnain, F., Syed, W., Akhtar, M. Usman. Effects of Brand Hate on Brand Equity: The Role of Corporate Social Irresponsibility and Similar Competitor Offer

negative feelings like brand hate which ultimately affect the product reputation, thus reducing its brand equity. Therefore organisations need to prevent intentionally brand avoidance behaviour to diminish negative brand feelings. Organisations must also be cautious not to create such events that generate consumer negativity for brands, thus damaging their brand equity (Rindell, 2013) severely. The results of the above study provide guidelines for marketers and managers alike. From the marketing viewpoint, firms should determine the grounds due to which customer changes his behaviour towards a brand. In turn, the current study suggests strategies to deal with brand haters. First, it is necessary for managers to continually measure and gauge their relationship with the customer service centre, front desk employees, or through social media. For the purpose to keep the monitoring system active, internal/external tracking is a vital step to manage consumer relationships with brand efficiently and effectively. Such strategies might appear beneficial for the firms which have dissatisfied customers. Secondly, among different individual's negative emotions trigger differently due to the intensity of the perceived value of similar competitor offer, which needs to be managed carefully. Note that similarity to competitor offer deals between brand and customer, whereas corporate social irresponsibility affects both consumers and nonconsumers. Furthermore, preventing any moral, social, ethical or legal wrongdoing would decrease consumer's corporate social irresponsibility with a brand. Therefore, corporate social irresponsibility must be dealt with first and with utmost care. It is worthwhile to mention that the firm could never satisfy its all customers/non-customers, but the efforts must be made to handle severe cases first that may have a profound impact on firms should be minimised.

The current research also contains some restrictions which could be the base for future research. This study aimed only at the tetra-Pak milk industry. Herewith, the obtained result could not be generalised to a large number of products and services. Thus such type of researchers should also be protracted to the other industries like electronics, automobiles etc. The sample of the current study was comprised of male and female teachers of public and private sector universities, colleges and schools. Enhancements in the sample and sampling technique should be done to validate the findings of the present study further. Experimental research design could be more insightful and should be incorporated to test such type of theoretical frameworks. Future studies should also examine the role of personality traits which is much accountable for propagating the feeling of hate. Moreover, other mechanisms and affective responses should also be taken into account in understanding the impact of similar competitor offer, corporate social irresponsibility and their subsequent effect on brand outcomes. For example, future studies may investigate the concepts of brand irritation, brand opposition and brand retaliation between brand similarity to competitor offer, corporate social irresponsibility and brand outcomes. Last but not least, the present study is a contribution to the field of consumer marketing in a developing country context like Pakistan. Furthermore, to validate the findings of the current research, future studies should examine such models in non-western contexts.

Author Contributions: conceptualisation, M. H. and F. S.; methodology, W. A.; software, M. H; validation, M. U., F. S. and M. H.; formal analysis, M. H.; investigation, W. A.; resources, W. A.; data curation, F. S.; writing-original draft preparation, M. H.; writing-review and editing, F. S.; visualisation, W. A.; supervision, M. U.; project administration, M. U.

Funding: This research received no external funding.

\section{References}

Aaker, D. A., \& Joachimsthaler, E. (2000). The brand relationship spectrum: The key to the brand architecture challenge. California management review, 42(4), 8-23. [Google Scholar] [CrossRef]

Abbas, M., Raja, U., Darr, W., \& Bouckenooghe, D. (2014). Combined effects of perceived politics and psychological capital on job satisfaction, turnover intentions, and performance. Journal of Management, 40(7), 1813-1830. [Google Scholar] [CrossRef]

Abid, R., \& Khattak, A. (2017). Brand avoidance motivators stimulate to brand equity in the mediating role of brand hate: A case of smartphone industry of Pakistan. Journal of Accounting and Marketing, 6(3), 250. [Google Scholar] 


\section{M., Husnain, F., Syed, W., Akhtar, M. Usman. Effects of Brand Hate on Brand Equity: The Role of Corporate Social Irresponsibility and Similar Competitor Offer}

Arena, S., Renzone, G., D’Ambrosio, C., Salzano, A. M., \& Scaloni, A. (2017). Dairy products and the Maillard reaction: A promising future for extensive food characterisation by integrated proteomics studies. Food Chemistry, 219, 477-489. [Google Scholar] [CrossRef]

Bagozzi, R. P., \& Yi, Y. (1988). On the evaluation of structural equation models. Journal of the academy of marketing science, 16(1), 74-94. [Google Scholar] [CrossRef]

Barrea, L., Di Somma, C., Macchia, P. E., Falco, A., Savanelli, M. C., Orio, F., ... \& Savastano, S. (2017). Influence of nutrition on somatotropic axis: Milk consumption in adult individuals with moderate-severe obesity. Clinical Nutrition, 36(1), 293-301. [Google Scholar] [CrossRef]

Boomsma, A. (1983). On the robustness of LISREL (maximum likelihood estimation) against small sample size and nonnormality. Rijksuniversiteit Groningen. [Google Scholar]

Brewer, M. B. (1991). The social self: On being the same and different at the same time. Personality and social psychology bulletin, 17(5), 475-482. [Google Scholar] [CrossRef]

Bryson, D., Atwal, G., \& Hultén, P. (2013). Towards the conceptualisation of the antecedents of extreme negative affect towards luxury brands. International Journal, 16(4), 393-405. [Google Scholar] [CrossRef]

Buil, I., De Chernatony, L., \& Martínez, E. (2013). Examining the role of advertising and sales promotions in brand equity creation. Journal of business research, 66(1), 115-122. [Google Scholar] [CrossRef]

Cole, D. A., \& Maxwell, S. E. (2003). Testing mediational models with longitudinal data: questions and tips in the use of structural equation modeling. Journal of abnormal psychology, 112(4), 558. [Google Scholar] [CrossRef]

Cook, T. D., \& Campbell, D. T. (1979). Quasi-experimentation: Design and analysis for field settings (Vol. 3): Rand McNally Chicago. [Google Scholar]

Delzen, M. V. (2014). Identifying the motives and behaviors of brand hate (Master's thesis, University of Twente). [Google Scholar]

Emari, H., Jafari, A., \& Mogaddam, M. (2012). The mediatory impact of brand loyalty and brand image on brand equity. African Journal of Business Management, 6(17), 5692-5701. [Google Scholar] [CrossRef]

Farjam, S., \& Hongyi, X. (2015). Reviewing the concept of brand equity and evaluating consumer-based brand equity (CBBE) models. International Journal of Management Science and Business Administration, 1(8), 14-29. [Google Scholar] [CrossRef]

Farooq, U., Tao, W., Alfian, G., Kang, Y. S., \& Rhee, J. (2016). ePedigree traceability system for the agricultural food supply chain to ensure consumer health. Sustainability, 8(9), 839. [Google Scholar] [CrossRef]

Fornell, C., \& Larcker, D. F. (1981). Structural Equation Models With Unobservable Variables and Measurement Error: Algebra and Statistics. Journal of Marketing Research (JMR), 18(3). [Google Scholar] [CrossRef]

Fournier, S., \& Alvarez, C. (2013). Relating badly to brands. Journal of Consumer Psychology, 23(2), 253-264. [Google Scholar] [CrossRef]

Gierl, H., \& Huettl, V. (2011). A closer look at similarity: The effects of perceived similarity and conjunctive cues on brand extension evaluation. International Journal of Research in Marketing, 28(2), 120-133. [Google Scholar] [CrossRef]

Gopinath, S., Lichtman, J. S., Bouley, D. M., Elias, J. E., \& Monack, D. M. (2014). Role of disease-associated tolerance in infectious superspreaders. Proceedings of the National Academy of Sciences, 111(44), 15780-15785. [Google Scholar] [CrossRef] Grappi, S., Romani, S., \& Bagozzi, R. P. (2013). Consumer response to corporate irresponsible behavior: Moral emotions and virtues. Journal of business research, 66(10), 1814-1821. [Google Scholar] [CrossRef]

Grégoire, Y., Tripp, T. M., \& Legoux, R. (2009). When customer love turns into lasting hate: The effects of relationship strength and time on customer revenge and avoidance. Journal of marketing, 73(6), 18-32. [Google Scholar] [CrossRef] Hegner, S. M., Fetscherin, M., \& van Delzen, M. (2017). Determinants and outcomes of brand hate. Journal of Product \& Brand Management, 13, 25. [Google Scholar] [CrossRef]

Jahanzeb, S., \& Fatima, T. (2018). How workplace ostracism influences interpersonal deviance: The mediating role of defensive silence and emotional exhaustion. Journal of Business and Psychology, 33(6), 779-791. [Google Scholar] [CrossRef]

Keller, K. L. (2014). Designing and implementing brand architecture strategies. Journal of Brand Management, 21(9), 702-715. [Google Scholar] [CrossRef

Kelloway, E. K. (1998). Using LISREL for structural equation modeling: A researcher's guide. Sage. [Google Scholar]

Khan, M. A., \& Lee, M. S. (2014). Prepurchase determinants of brand avoidance: The moderating role of country-of-origin familiarity. Journal of Global Marketing, 27(5), 329-343. [Google Scholar] [CrossRef]

Klein, J., \& Dawar, N. (2004). Corporate social responsibility and consumers' attributions and brand evaluations in a productharm crisis. International Journal of research in Marketing, 21(3), 203-217. [Google Scholar] [CrossRef]

Kline, R. B. (1998). Software review: Software programs for structural equation modeling: Amos, EQS, and LISREL. Journal of psychoeducational assessment, 16(4), 343-364. [Google Scholar] [CrossRef]

Kotler, P., \& Armstrong, G. (2010). Principles of marketing. Pearson education. [Google Scholar]

Kotrlik, J. W., \& Higgins, C. (2001). Organisational research: Determining appropriate sample size in survey research appropriate sample size in survey research. Information technology, learning, and performance journal, 19(1), 43. [Google Scholar] $\underline{\text { Scholar] }}$

Kucuk, S. U. (2008). Consumer Exit, Voice, and'Power' on the Internet. Journal of Research for Consumers, (15). [Google

Lee, M. S., Motion, J., \& Conroy, D. (2009). Anti-consumption and brand avoidance. Journal of Business Research, 62(2), 169- 


\section{M., Husnain, F., Syed, W., Akhtar, M. Usman. Effects of Brand Hate on Brand Equity: The Role of Corporate Social}

Irresponsibility and Similar Competitor Offer

180. [Google Scholar] [CrossRef]

Mohan, B. C., \& Sequeira, A. H. (2016). The impact of customer-based brand equity on the operational performance of FMCG companies in India. IIMB Management Review, 28(1), 13-19. [Google Scholar] [CrossRef]

Moslehi, J. J., \& Deininger, M. (2015). Tyrosine kinase inhibitor-associated cardiovascular toxicity in chronic myeloid leukemia. Journal of clinical oncology, 33(35), 4210. [Google Scholar] [CrossRef]

Nenycz-Thiel, M., \& Romaniuk, J. (2011). The nature and incidence of private label rejection. Australasian Marketing Journal (AMJ), 19(2), 93-99. [Google Scholar] [CrossRef]

Nunnally, J. (1978). Psychometric methods: New York: McGraw-Hill.

Ojha, K. S., Mason, T. J., O'Donnell, C. P., Kerry, J. P., \& Tiwari, B. K. (2017). Ultrasound technology for food fermentation applications. Ultrasonics sonochemistry, 34, 410-417. [Google Scholar] [CrossRef]

Pappu, R., Quester, P. G., \& Cooksey, R. W. (2005). Consumer-based brand equity: improving the measurement-empirical evidence. Journal of Product \& Brand Management, 143, 154. [Google Scholar] [CrossRef]

Preijers, S. (2016). Brand hate; Exploring and understanding the concept. [Google Scholar]

Saleem, H. A., Rashid, S. M., \& Aslam, R. (2014). The Impact of Brand Extension on Parent Brand Image. International Journal of Humanities and Social Science, 4(2), 10.

Reporter. (2017). Only six milk brands found fit for consumption in Pakistan. Retriewed from https://www.dawn.com/news/1311792

Rindell, A. (2013). Time in corporate images: introducing image heritage and image-in-use. International Journal, 16(2), 197213. [Google Scholar] [CrossRef]

Rodrigues, L., \& Karlsson, D. (2015). Why Do We Hate Brands?: A qualitative study of how the dark side of branding is influenced by group identification. [Google Scholar]

Romani, S., Grappi, S., Zarantonello, L., \& Bagozzi, R. P. (2015). The revenge of the consumer! How brand moral violations lead to consumer anti-brand activism. Journal of Brand Management, 22(8), 658-672. [Google Scholar] [CrossRef]

Sampedro, A. (2017). Brand hate and brand forgiveness-A dynamic analysis. [Google Scholar]

Sarkar, J. G., \& Sarkar, A. (2017). Investigating young customers' retail purchase embarrassment. Marketing intelligence \& planning, 35(1), 111-129. [Google Scholar] [CrossRef]

Schmidt, A., Pratsch, H., Schreiner, M. G., \& Mayer, H. K. (2017). Determination of the native forms of vitamin B1 in bovine milk using a fast and simplified UHPLC method. Food chemistry, 229, 452-457. [Google Scholar] [CrossRef]

Shamsudin, M., Esa, S., \& Ali, A. (2019). Determinants of customer loyalty towards the hotel industry in Malaysia. International Journal of Innovation, Creativity and Change, 6(9), 21-29. [Google Scholar]

Shuv-Ami, A. (2012). Brand commitment: A new four-dimensional (4 Es) conceptualisation and scale. Journal of Customer Behaviour, 11(3), 281-305. [Google Scholar] [CrossRef]

Sivo, S. A., Fan, X., Witta, E. L., \& Willse, J. T. (2006). The search for «optimal» cutoff properties: Fit index criteria in structural equation modeling. The Journal of Experimental Education, 74(3), 267-288. [Google Scholar] [CrossRef]

Steinman, R. B., \& Wolfrom, B. T. (2012). The effect of brands' unethical actions on consumers' attitudes in the fast moving consumer goods domain. Business Management Dynamics, 2(3), 32. [Google Scholar]

Sternberg, R. J. (2003). A duplex theory of hate: Development and application to terrorism, massacres, and genocide. Review of General Psychology, 7(3), 299-328. [Google Scholar] [CrossRef]

Stokburger-Sauer, N., Ratneshwar, S., \& Sen, S. (2012). Drivers of consumer-brand identification. International journal of research in marketing, 29(4), 406-418. [Google Scholar] [CossRef]

$\mathrm{Su}, \mathrm{J}$. (2016). Examining the relationships among the brand equity dimensions: empirical evidence from fast fashion. Asia Pacific Journal of Marketing and Logistics, 28(3), 464-480. [Google Scholar] [CrossRef]

Tsarenko, Y., \& Tojib, D. (2015). Consumers' forgiveness after brand transgression: the effect of the firm's corporate social responsibility and response. Journal of Marketing Management, 31(17-18), 1851-1877. [Google Scholar] [CrossRef]

Vance, N. R., \& Harris, A. S. (2011). Ethics as management principles. Journal of Leadership, Accountability, and Ethics, 8(3), 11-21. [Google Scholar]

Wardle, J., Haase, A. M., Steptoe, A., Nillapun, M., Jonwutiwes, K., \& Bellisie, F. (2004). Gender differences in food choice: the contribution of health beliefs and dieting. Annals of behavioral medicine, 27(2), 107-116. [Google Scholar] [CrossRef]

Wry, T., \& Castor, A. R. (2017). Opportunity, Status, and Similarity: Exploring the Varied Antecedents and Outcomes of Category Spanning Innovation', From Categories to Categorisation: Studies in Sociology, Organisations and Strategy at the Crossroads (Research in the Sociology of Organisations, Volume 51). [Google Scholar] [CrossRef]

Yousaf, A., Gupta, A., \& Mishra, A. (2017). Sport team brand-equity index: a new measurement. Journal of Indian Business Research, 9(2), 169-188. [Google Scholar] [CrossRef]

Zaheer, F. (2017). Need to spread awareness on packaged milk. Retrieved from https://tribune.com.pk/story/1381006/needspread-awareness-packaged-milk

Zarantonello, L., Romani, S., Grappi, S., \& Bagozzi, R. P. (2016). Brand hate. The Journal of Product and Brand Management, 25(1), 11. [Google Scholar] [CrossRef]

Zhang, C. (2017). Brand Hate. Concordia University. Retrieved from
https://spectrum.library.concordia.ca/982688/1/Zhang_PhD_F2017.pdf 
M., Husnain, F., Syed, W., Akhtar, M. Usman. Effects of Brand Hate on Brand Equity: The Role of Corporate Social Irresponsibility and Similar Competitor Offer

Мудассір Хуснейн, Міжнародний ісламський університет в Ісламабаді, Пакистан

Фаузія Сієд, Ph.D., Міжнародний ісламський університет в Ісламабаді, Пакистан

Уахід Ахтар, Міжнародний ісламський університет в Ісламабаді, Пакистан

Мухаммед Усман, Ph.D., Університет освіти, Пакистан

Вплив рівня антилояльності бренда на його вартість: роль корпоративної соціальної безвідповідальності та індентичних конкурентих переваг

Ця стаття узагальнює аргументи та контраргументи в межах наукової дискусії з питань теорії антилояльності до бренда. Емпіричне дослідження проведено на основі панельних даних, сформованих для вибірки з респодентів освітньої галузі Пакистану, що були згенеровані за допомогою методу иілеспрямованого відбору учасників. Збір вихідних даних для дослідження проведено у три етапи: 1) розсилка 800 анкет між учасниками опитування, з яких 772 було заповнено і повернуто; 2) розсилка 2722 анкет (600 заповнено і повернуто); 3) розсилка 3600 анкет (550 заповнено і повернуто). Для аналізу панельних даних застосовано моделювання структурних рівнянь. За отриманими результатами дослідження підтверджено вплив антилояльності до бренда на його вартість. У статті встановлено, що втрата індивідуальності бренда провокує негативне відношення споживачів до нього. Як наслідок, вартість даного бренда знижується. Авторами зазначено, що корпоративна соціальна безвідповідальність є потужним предиктором негативних емоцій споживачів. Так, корпоративна соціальна безвідповідальність являється тригером зростання рівня антилояльності споживачів до бренда, що спричиняє зниження його вартості. Авторами зазначено, що невілювання корпоративної соціальної безвідповідальност дозволить уникнути негативного впливу на вартість бренду. У свою чергу, антилояльність до бренду впливає на ставлення споживачів до нього. У статmі наголошено, що компаніям необхідно впроваджувати маркетинговові програми просування власного бренду та посилювати комунікацію зі споживачами з метою зниження рівня їх антилояльності до бренду. Авторами виокремлено основні маркетингові канали, які забезпечують формування позитивного іміджу компанії за умови наявності індентичних конкурентих переваг на ринку. Для подальших досліджень необхідним є аналіз більшої вибірки даних з урахуванням географрічної ознаки.

Ключові слова: дворівнева теорія ненависті, споживач тетрапаку, схожість пропозицій конкурентів, ненависть бренда, брендовий капітал, корпоративна соціальна безвіповідальність.

Manuscript received: 09.07.2020

(c) The author(s) 2020. This article is published with open access at Sumy State University 